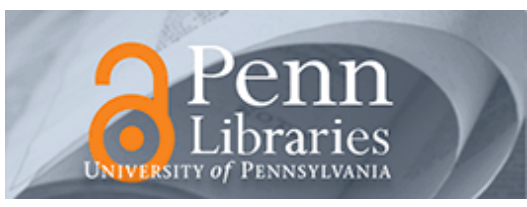

University of Pennsylvania ScholarlyCommons

Wharton Pension Research Council Working

Papers

Wharton Pension Research Council

6-1-2009

\title{
Default, Framing and Spillover Effects: The Case of Lifecycle Funds in 401(k) Plans
}

Olivia S. Mitchell

The Wharton School, University of Pennsylvania, mitchelo@wharton.upenn.edu

Gary R. Mottola

Vanguard Center for Retirement Research,gmottola@vanguard.com

Stephen P. Utkus

Vanguard Center for Retirement Research, steve_utkus@vanguard.com

Takeshi Yamaguchi

The Wharton School, University of Pennsylvania, tyamaguc@wharton.upenn.edu

Follow this and additional works at: https://repository.upenn.edu/prc_papers

Part of the Economics Commons

Mitchell, Olivia S.; Mottola, Gary R.; Utkus, Stephen P.; and Yamaguchi, Takeshi, "Default, Framing and Spillover Effects: The Case of Lifecycle Funds in 401(k) Plans" (2009). Wharton Pension Research Council Working Papers. 326.

https://repository.upenn.edu/prc_papers/326

This paper is posted at ScholarlyCommons. https://repository.upenn.edu/prc_papers/326

For more information, please contact repository@pobox.upenn.edu. 


\title{
Default, Framing and Spillover Effects: The Case of Lifecycle Funds in 401(k) Plans
}

\begin{abstract}
Important behavioral factors such as default and framing effects are increasingly being employed to optimize decision-making in a variety of settings, including individually-directed retirement plans. Yet such approaches may have unintended "spillover" effects, as we show with regard to the introduction of lifecycle funds in U.S. 401(k) plans. As anticipated, lifecycle funds do reshape individual portfolio choices through large default and framing effects. But unexpectedly, they also create a new class of investors which holds these funds as part of more complex portfolios. Our results are directly relevant to those interested in retirement plan design and retirement security; they also highlight the importance of assessing such spillover effects in other consequential settings where techniques drawn from behavioral economics may be employed.
\end{abstract}

\section{Disciplines}

Economics 


\title{
Default, Framing and Spillover Effects: The Case of Lifecycle Funds in 401(k) Plans
}

\author{
Olivia S. Mitchell, Gary R. Mottola, Stephen P. Utkus and Takeshi Yamaguchi
}

June 2009

\author{
PRC WP2009-05 \\ Pension Research Council Working Paper \\ Pension Research Council \\ The Wharton School, University of Pennsylvania \\ 3620 Locust Walk, 3000 SH-DH \\ Philadelphia, PA 19104-6302
}

Tel: 215.898.7620 Fax: 215.573.3418

Email: prc@wharton.upenn.edu

http://www.pensionresearchcouncil.org

\begin{abstract}
This research is part of the NBER programs on Aging and Labor Economics and was undertaken pursuant to a grant from the US Social Security Administration (SSA) to the Michigan Retirement Research Center (MRRC). This research support is gratefully acknowledged along with that of the Pension Research Council at The Wharton School and Vanguard. The authors also acknowledge Vanguard's efforts in the provision of recordkeeping data under restricted access conditions. They benefited from the suggestions of Brigitte Madrian, Alexander Muermann, and Stephen Shore. Opinions, errors, and conclusions are solely those of the authors and do not represent the views of the SSA, any agency of the Federal Government, Vanguard, the MRRC, the Pension Research Council, or any other institution with which the authors may be affiliated. (C)2009 Mitchell, Mottola, Utkus and Yamaguchi. (C) 2009 Pension Research Council of the Wharton School of the University of Pennsylvania. All rights reserved.
\end{abstract}




\title{
Default, Framing and Spillover Effects: The Case of Lifecycle Funds in 401(k) Plans
}

\begin{abstract}
Important behavioral factors such as default and framing effects are increasingly being employed to optimize decision-making in a variety of settings, including individually-directed retirement plans. Yet such approaches may have unintended "spillover" effects, as we show with regard to the introduction of lifecycle funds in U.S. 401(k) plans. As anticipated, lifecycle funds do reshape individual portfolio choices through large default and framing effects. But unexpectedly, they also create a new class of investors which holds these funds as part of more complex portfolios. Our results are directly relevant to those interested in retirement plan design and retirement security; they also highlight the importance of assessing such spillover effects in other consequential settings where techniques drawn from behavioral economics may be employed.
\end{abstract}

Olivia S. Mitchell (corresponding author)

International Foundation of Employee Benefit Plans Professor

Professor of Insurance \& Risk Management

Department of Insurance and Risk Management, The Wharton School, University of Pennsylvania

3620 Locust Walk, Suite 3000-SHDH, Philadelphia, PA 19104

Tel. 215-898-0424

mitchelo@wharton.upenn.edu

\section{Gary R. Mottola}

Researcher, Vanguard Center for Retirement Research

100 Vanguard Boulevard, M38

Malvern, PA 19355

Tel. 610-503-4808

gmottola@vanguard.com

\section{Stephen P. Utkus}

Principal, Vanguard Center for Retirement Research

100 Vanguard Boulevard, M38

Malvern, PA 19355

Tel. 610-669-6308

steve_utkus@vanguard.com

\section{Takeshi Yamaguchi}

Pension Research Council, The Wharton School, University of Pennsylvania

3620 Locust Walk, Suite 3000-SHDH

Philadelphia, PA 19104

tyamaguc@wharton.upenn.edu 


\section{Default, Framing and Spillover Effects: The Case of Lifecycle Funds in 401(k) Plans}

\section{Introduction}

Default options and framing techniques have both emerged as useful strategies for remedying numerous apparent deficiencies in individual decision-making. For example, in the case of U.S. defined contribution (DC) plans, the U.S. Treasury in 1997 introduced an opt-out or automatic enrollment regime in an effort to boost worker retirement saving. This design change dramatically improved saving by low-wage and younger workers. The success of automatic enrollment has in turn prompted a broader discussion of the role that "choice architecture" might play in optimizing decisions in other domains, such as the environment, consumer protection, and health care (Thaler and Sunstein, 2008).

Following on this earlier success, the U.S. Department of Labor in 2007 sanctioned a new class of default investments for DC retirement plans (known as qualified default investment alternatives or QDIAs) under the Pension Protection Act. The aim of this new policy was to improve portfolio allocations among defaulted participants. One popular type of QDIA, known as lifecycle or target maturity funds, are pension investment options that radically simplify portfolio allocation decisions. ${ }^{1}$ With a lifecycle investment offering, plan participants select a portfolio based only on an expected year of retirement. The fund's portfolio manager is responsible for all portfolio construction decisions, including initial allocations, daily rebalancing and portfolio changes over the lifecycle. When offered on a voluntary (non-automatic) basis, lifecycle funds might be expected to appeal to individuals with little or no experience with

\footnotetext{
${ }^{1}$ In this paper we reserve the term "lifecycle fund" for the lifecycle concept. The term "lifecycle" is sometimes broadened to include risk-based static allocation (SA) funds, such as conservative, moderate or aggressive funds. SA funds are increasingly referred to as "lifestyle" funds.
} 
portfolio allocation decisions - we refer to this as the investment framing effect, as it reframes a complex portfolio choice decision as a simpler one. When these are designated by the plan sponsor as a default investment, lifecycle funds would be expected to alter portfolio allocations because of inertia - a default effect. But as we show in this paper, default and framing effects are an incomplete account of the behavioral impact of changing the "choice architecture" in retirement plans. Drawing on a rich dataset of nearly a quarter-million 401(k) participants covered by over 250 plans in a variety of default and voluntary choice settings, we find that the introduction of lifecycle funds also produces an unexpected result: it prompts the growth of a sizeable new class of investors which uses these funds in unanticipated ways. This unanticipated change in behavior we refer to as a "spillover" effect.

Our paper builds on an important literature regarding default effects in retirement plans, particularly with respect to savings decisions (Madrian and Shea, 2001; Choi et al., 2003, 2005, 2006; Nessmith, Utkus and Young, 2007). It also builds upon an extensive body of literature on portfolio allocation and trading choices, both in retirement plans and personal accounts (O’Donoghue and Rabin, 1999; 2001; Benartzi, 2001; Benartzi and Thaler, 2001, 2002; Ameriks and Zeldes, 2004; Agnew, Balduzzi, and Sunden, 2003; Mitchell, Mottola, Utkus, and Yamaguchi, 2006a and 2006b; Benartzi, Peleg and Thaler, 2007; Calvet, Campbell and Sodini, 2009). We also draw directly from earlier findings that retirement plan investment menus frame individual portfolio allocation decisions in sizeable ways, either as a result of inertia or naïve decision-making (Benartzi and Thaler, 2001, 2002; Huberman and Jiang, 2006; Brown, Liang and Weisbenner; 2006) or in reaction to excessive complexity, also known as "choice overload" (Iyengar, Huberman and Jiang, 2004; Iyengar and Jiang, 2006). Two of these studies (Benartzi, 2001; Choi et. al., 2003) demonstrate similar unintended consequences among individuals who 
are affected by default designations. But our results offer a more expansive understanding of the effects of changes in decision architectures. As with prior studies, we confirm that default and framing effects reshape individual choices and help explain many behavioral effects. But these factors do not account for the full range of outcomes: indeed, as we show here, large unexpected or spillover effects arise among individuals making voluntary choices, and in the case of lifecycle funds, the latter can be as significant as the original intended default effects.

In what follows, we begin by describing our dataset and the rich complexity that arises with the introduction of lifecycle funds in 401(k) plans. The empirical approach first considers models of lifecycle fund adoption; next we analyze the impact that such adoption has on portfolio characteristics. We conclude with a discussion of the implications of our findings for retirement policy and more broadly for models of behaviorally-influenced decision-making.

\section{Data and Descriptive Statistics}

To assess how the introduction of lifecycle funds affects 401(k) decision-making, we investigate a unique panel dataset covering 258 defined contribution plans drawn from Vanguard's 401(k) recordkeeping system. The full sample used to explore adoption patterns includes over 252,000 active participants in plans that introduced lifecycle funds during 2003-05; all participants entering and leaving the plans due to normal workforce turnover are included in the full sample. ${ }^{2}$ Variables available for empirical analysis include a wealth of detail on 401(k) account balances, investment holdings, and account contributions, ${ }^{3}$ as well as key socioeconomic

\footnotetext{
${ }^{2}$ Active 401(k) participants are those who are currently contributing to their employer's retirement plan.

${ }^{3}$ We focus our portfolio analysis on $401(\mathrm{k})$ contributions rather than fund balances because contributions are more reflective of forward-looking intentions and unbiased by prior holdings.
} 
characteristics including age, sex, household income, and non-retirement financial wealth. ${ }^{4}$ Also available are important features about each plan's offered investment menu, including the number and types of investment funds offered and other plan design details. In addition, our dataset includes monthly returns for all investments offered over an eight-year period (including the three-year period under analysis as well as the five years preceding it).

Table 1 outlines the key attributes of the lifecycle funds introduced by our employers over the period under study. Each lifecycle fund is named according to its target maturity date; each involves a different mix of passively-managed US equity (including large-, mid- and smallcapitalization stocks), international equity (both developed and emerging markets), and US highquality bonds. Panel A indicates that total equity exposure in the funds for the younger participants averages 89 percent (in the 2035 and 2045 Funds) versus 29 percent for older participants in the Income Fund intended for those in their 60s and beyond. Panel B of Table 2 depicts how the lifecycle funds were introduced. In 45 percent of the plans lifecycle funds were introduced de novo while in 55 percent of the plans, the participants had been previously offered static allocation (SA) or risk-based funds. In this latter group, one set of plans added lifecycle funds to a menu that included pre-existing SA funds, while the other group switched or "mapped" the plans from SA to lifecycle funds. ${ }^{5}$ Finally, in some cases, the employer designated the new lifecycle funds as the plan default. The default option influences mainly new hires who are automatically enrolled (or who enroll on a voluntary basis but failed to submit an investment election with their enrollment).

\footnotetext{
${ }^{4}$ Household income is imputed based on zip codes as is non-retirement financial wealth, and is provided by the IXI Company.

${ }^{5}$ In the case of mapping from SA to lifecycle funds, sponsors could either switch all participant SA balances and contributions into the new lifecycle funds, or allow existing balances to remain undisturbed while switching future contributions into lifecycle funds. In both cases, the new lifecycle allocations would reflect the sponsor's decision to move the money, rather than representing an active employee election.
} 


\section{Table 1 here}

Table 2 summarizes characteristics of the plans and covered workers. There is substantial diversity by age, income, 401(k) account balance, and non-retirement financial wealth in our full sample (Column 1). Nearly one-fifth are new hires. The mean 401(k) balance is just over $\$ 64,000$.

\section{Table 2 here}

From this aggregate sample, we draw a group of lifecycle adopters for use in a difference-in-difference (D-D) analysis of portfolio effects. This subset consists of lifecycle adopters who were continuously employed in our panel during the 2003-2005 period; in other words, it excludes new hires. Because default designations in our sample overwhelmingly apply only to new hires, this group excludes defaulted new hires, and only consists of participants who voluntarily chose lifecycle funds once they were introduced into their 401(k) plans. Comparing these lifecycle participants with the full sample (Columns 1 and 2), we see that (non-defaulted) lifecycle adopters tend to be younger, more female, and earn less than the full sample; they also have lower 401(k) balances.

Lifecycle funds by their nature are intended as a single or complete portfolio. In keeping with this intent, almost half ( $n=10,750$ or 44 percent) of those in the D-D sample are "pure" adopters and direct their entire contributions to lifecycle funds (Column 3). The remainder of the adopters ( $n=13,862$ or $56 \%$ ) utilize lifecycle funds in an unexpected way: they contribute to lifecycle funds along with other investment options in their portfolio (Column 4). ${ }^{6}$ Pure (nondefault) adopters are younger and more female compared to mixed (non-default) adopters, and

\footnotetext{
${ }^{6}$ Over $95 \%$ of pure adopters contribute to only one lifecycle fund; mixed adopters contribute to 4.5 funds on
} average. 
they have lower 401(k) balances and non-retirement financial wealth. By comparison, mixed (non-default) adopters tend to be older, more affluent males.

\section{Factors Influencing the Adoption of Lifecycle Funds}

Retirement plan participants may come to invest in lifecycle funds in a variety of ways. First, the employer may designate the lifecycle funds as a default investment. As a result, participants who are automatically enrolled (or who voluntarily decide to contribute but fail to submit an investment election) are directed by design into an appropriate age-based fund, thus eliciting a so-called default effect. Second, lifecycle funds may be offered to participants on a voluntary (non-default) basis. The lifecycle funds examined here add neither new asset classes nor investment management styles to the retirement plans we examine. As a result, participants electing them on a non-default basis would presumably be doing so because the funds simplify the portfolio allocation decision - what we refer to as the investment framing effect. But third, in the voluntary choice setting that characterizes $401(\mathrm{k})$ investment decision-making, participants may choose to invest in lifecycle funds using a more complex portfolio strategy, combining them with other plan investments. This is the unintended spillover effect.

To assess the factors associated with each of these three outcomes—default, framing and spillover effects-we begin with a straightforward Probit analysis of lifecycle fund adoption. In equation (1), LCAdopter $_{i, j, t}$ refers to the probability that the $i$ th participant holds a lifecycle fund in the $j$ th plan in month $t$ as follows:

$$
\text { LCAdopter }_{i, j, t}=\alpha P A R T I C I P A N T+\beta P L A N+\gamma T R E A T M E N T+v_{i}+\tau_{t}+\omega_{j}+\varepsilon_{i, j, t}
$$


where the dependent variable takes a value of 1 if the participant invests in a lifecycle fund in month $t$, and 0 otherwise. The mean value of this time-weighted adoption rate is $15.1 \%{ }^{7}$ For this analysis we use the full data (as described in Table 2), which includes both continuously employed participants as well as new hires entering the plan for the first time. The PARTICIPANT vector includes a New Entrant identifier indicating whether the participant entered the plan after the lifecycle funds were offered ( 0 otherwise). The TREATMENT vector measures aspects associated with the way in which lifecycle funds were introduced: for instance, a Default indicator indicates whether the new lifecycle funds were designated as the default investment option. We also interact Default and New Entrant to reveal the effect of new plan entrants being defaulted into the lifecycle funds. ${ }^{8}$ In addition, we control on the number of months since lifecycle funds were introduced, Time Count (and that same variable squared), to indicate the time path of impact of lifecycle adoption. The model also incorporates participant socioeconomic characteristics including age, income, sex, and non-retirement financial wealth. To control on cross-plan differences, the PLAN vector indicates the number of fund choices on offer, a dummy indicating company stock is available in the 401(k) plan, and an indicator of loan availability. For reasons noted above, we also control on $S A$ Before which indicates whether static allocation funds had been previously offered. ${ }^{9}$

\footnotetext{
${ }^{7}$ The mean value of lifecycle adoption is not $10 \%$ (in Table 1, 24,612 lifecycle adopters divided by 252,980 participants) because our measure is weighted according to the months in which lifecycle funds were offered. For example, if lifecycle funds were offered in a given plan during 18 months of our analysis period, and a participant in that plan contributed to those funds over nine months, his adoption rate would be $50 \%$.

${ }^{8}$ Not all new entrants are new hires. Many of the plans in our sample allow immediate eligibility for the plan to new hires though a minority imposes a six- or twelve-month waiting period.

${ }^{9}$ The econometric models correct for plan-level heteroskedasticity $\left(v_{i}\right)$, time fixed effects $\left(\tau_{t}\right)$, and industry fixed effects, along with missing data controls.
} 
Table 3 reports estimated coefficients and marginal effects for the Probit regression. The most prominent finding is the strength of the default effect: if an employer designates lifecycle funds as the default investment, the likelihood of participants adopting the funds surges by 10.9 percentage points, an increase of $66 \%$ in the mean adoption rate. (This might be called the "PPA effect," a measure of how much participation in lifecycle funds rises as a result of employers’ decisions to designate lifecycle funds as plan default investments under the 2006 Pension Protection Act.) The default effect for new participants is even higher, indicating that newly eligible employees are 14.5 percentage points more likely to elect lifecycle funds when the employer offers these as the default investment.

\section{Table 3 here}

While the default effect is strong, lifecycle funds also prove to attract participants making voluntary choices. This framing effect is quite powerful among new hires: even when the fund is not the default, new hires are still 6.6 percentage points more likely to adopt lifecycle funds. In addition, lifecycle funds are also more likely to be adopted by participants with characteristics typically associated with low levels of financial literacy (Lusardi and Mitchell, 2007). In our regression results, young and female participants, as well as those with low 401(k) balances and low levels of non-financial retirement wealth, are more likely to invest in lifecycle funds on a voluntary (non-default) basis. With their ultra-simple decision framework, lifecycle funds eliminate the need to make complex portfolio construction decisions.

Two other subtleties are associated with the framing effects of lifecycle funds. Voluntary adoption of the funds appears to evolve linearly with time, such that each month following the introduction of the funds boosts adoption rates by 0.4 points. In other words, the framing effect becomes more attractive to participants with time. Also offering more funds in the 401(k) menu 
slightly reduces participation in lifecycle funds. The effect is small (having 10 additional funds means a two percentage point lower chance of holding lifecycle funds) but it does suggest that the appeal of lifecycle funds is contingent on the breadth of the other investment offerings.

The results summarized in Table 3 combine pure investors (adopting only a single lifecycle fund) with mixed investors (combining lifecycle funds with other investments). These mixed investors are evidence of our unintended or second-order spillover effect. To further disentangle differences between pure versus mixed lifecycle adopters, Table 4 reports marginal effects calculated from a multinomial Logit model where the dependent variable equals 1 if the participant is a mixed adopter; 2 if he is a pure adopter; and 0 if he is a nonadopter (the reference group). The explanatory variables are the same as in the prior Probit model. Measured on a timeweighted adoption basis, there are somewhat more pure adopters (8.6 percent of the sample) versus mixed (7.7 percent).

\section{Table 4 here}

For the pure investors, we see a default effect similar in magnitude to the prior Probit model: the default designation raises adoption by 5 points on a time-weighted adoption rate base of 8.6 percent, or 58 percent on a relative basis. The framing effects for pure investors are also similar: new entrants are more likely to be pure adopters, as are young, female, low income, low 401(k) balance and low non-retirement wealth participants. The prevalence of pure adoption also rises over time. By contrast, mixed adopters are unlike pure adopters along a number of dimensions: for instance, they are less influenced by the plan's default fund designation compared to pure adopters. Also the impact of the default designation on new hires is actually negative: new hires who are defaulted are more likely to be pure adopters and less likely to be mixed adopters. Demographically, mixed investors are likely to be younger and female, but 
relatively less so than pure adopters. Moreover, they tend to be middle income and middlewealth participants compared to non-adopters. Mixed investors, in other words, do not appear to possess the types of demographic characteristics or default behavior typically associated with low levels of financial sophistication. It is true that they could simply be a group of middleincome and middle-wealth participants plagued by naïve diversification, combining lifecycle funds with other options at random (Benartzi and Thaler, 2001). But another possibility is that they are engaged in a more sophisticated approach to investing. ${ }^{10}$ Additional survey research is needed to elicit the types of motivations driving the construction of these mixed portfolio strategies. But at least from our data set, we can ascertain that the motivations, whether rational or naïve, are disproportionately linked to middle-income and middle-wealth participants.

In sum, introducing lifecycle accounts have differential default and framing effects across pension plan participants. Altering the 401(k) choice architecture generates both intended and unintended consequences: default and framing effects are statistically and economically meaningful among pure investors, but the spillover effect is sizeable and results in the creation of a new class of mixed investors.

\section{Portfolio Changes Arising from the Introduction of Lifecycle Funds}

We turn next to an assessment of how participant portfolios respond to changes in the choice architecture of $401(\mathrm{k})$ plans. Life cycle funds are structured so that portfolio risk levels decline with age following a so-called "equity glide path": younger participants intending to retire further in the future will have a higher equity fraction and less fixed income, while older

\footnotetext{
${ }^{10}$ For example, mixed adopters may only want to have a portion of their portfolio to be automatically rebalanced, or they may be engaging in a "core/satellite" strategy of having the lifecycle fund as a core holding, supplemented by satellite funds.
} 
investors in these age-linked funds would hold less risky portfolios. In a rational agents' world, we would not expect the introduction of lifecycle funds to alter the age structure of equity allocations. But if participants are swayed by default and framing and spillover effects, we might expect that lifecycle funds will alter the equity gradient among participants. It is also worth noting that the lifecycle funds in our sample are passive or index-based, and the participants in our sample could have accessed a broad-based market index portfolio on their own, separate from the lifecycle funds. As a result, in a world in which 401(k) decision-makers are unduly influenced by behavioral biases, we might anticipate that the introduction of low-cost indexed lifecycle funds would reduce the share of idiosyncratic risk in portfolios.

We use a difference-in-difference model to evaluate the impact of lifecycle fund adoption on portfolio characteristics. Since we must observe a "before" portfolio (before lifecycle funds were introduced), as well as an "after” portfolio, we omit new entrants and hence new workers who were directly defaulted into lifecycle funds. For this reason, our difference-in-difference analysis is based on the subset of approximately 25,000 participants who adopted a lifecycle fund on a voluntary (non-default) basis, and focuses on framing and spillover (but not default) effects.

Table 5 describes investment attributes of lifecycle adopter portfolios before and after lifecycle funds join the menu, specifically, one month prior to adoption (time $t$-1) and six months later (time $t+0) .{ }^{11}$ Panel A summaries the allocation of participant contributions by major asset class including cash (money market or guaranteed investment contracts), bonds, balanced or lifecycle (and/or lifestyle) funds, US equities, employer stock, and international equities.

\footnotetext{
${ }^{11}$ Because we observe participants six months after lifecycle funds are offered, both the full sample and subset of adopters include only plans which introduced lifecycle funds by 6/05. The lifecycle adopter subset has 7 fewer plans because these had no lifecycle adopters as of December 12/05. Of the 252,000 participants in the full dataset, 189,968 were included in their plan both one month before and six months after the lifecycle funds were introduced.
} 
Overall, lifecycle adopters held more cash, bonds, and equity funds before the introduction of the lifecycle funds; afterwards, their balanced and lifecycle holdings rises by 12 percent. It is also interesting that many lifecycle adopters contributed to balanced or static allocation funds before the new lifecycle funds were introduced; these funds account for 79 percent of pure adopters' and 35 percent of mixed adopters' contributions. This finding points to the importance of controlling on the prior presence of the pre-existing menu design in order to evaluate the impact of lifecycle funds on participant behavior. Pure lifecycle adopters cut their cash position by almost five percent and their pure US equity holdings by 11 percent, and increase by 21 percent their ownership of balanced funds; the impact is smaller for mixed lifecycle adopters.

\section{Table 5 here}

Panel B of Table 5 displays three portfolio attributes measured for lifecycle adopters, again on a pre/post basis. The first attribute is the percent of the portfolio held in equities, ${ }^{12}$ where we see that, before the menu changed, the average lifecycle adopter directed two-thirds of his contributions to equities. After the introduction of the lifecycle fund, equity allocations rise by 1.4 percent for all adopters, with pure adopters devoting somewhat less and mixed adopters somewhat more to equity. The second column of Panel B illustrates how participant portfolios change in terms of overall systematic or risk-adjusted return. A participant's systematic return is the sum of the risk-free rate during the period, $r_{f}$, and each participant's factor return, or $r_{i, t}^{e}$, derived from a three-factor asset pricing model. ${ }^{13}$ The results show that expected returns rise

\footnotetext{
${ }^{12}$ Equity allocation is equal to the percentage of contributions directed to US equity funds, international equity funds, company stock, and a percentage of balance/lifecycle funds. The equity percentage for balanced/lifecycle funds was calculated based on each fund's investment policies and varies from fund to fund.

${ }^{13}$ Factor returns are computed using a three-factor model based on US equities, US bonds, and international equities because, as noted earlier, the lifecycle funds in our dataset are composed of index-based funds mirroring these three asset classes. To calculate portfolio returns we construct a risk-loading matrix for all $k$ investment options in our dataset by regressing the excess return (over Treasury bill returns) for each of the $k$ assets in our universe on three
} 
across the board for all adopters as well as for pure and mixed adopters (before controlling on other factors including time effects; we say more on this below). Also the difference in expected returns between pure and mixed adopters is small. For example, on a "before" basis, mixed adopters held 15 percent more equity than pure adopters (70.7 is 15 percent higher than 61.4 ), but their returns were only two percent higher (6.52 is two percent greater than 6.38). This suggests that those who later become pure lifecycle investors had successfully constructed more efficient portfolios with lower equity exposure but similar expected returns, mainly through static allocation (lifestyle) and balanced fund holdings. ${ }^{14}$

A third portfolio attribute reported in Table 3 is the ratio of idiosyncratic portfolio risk as a fraction of total portfolio variance, $N S R / T V_{i, t} \cdot{ }^{15}$ This measure describes how much of portfolio variance is explained by nonsystematic or non-market factors. By definition, nonsystematic risk should be zero when all of a participant's contributions are directed to index-

market indices: the value-weighted CRSP portfolio, the Lehman Brothers Aggregate Bond Index (LBA), and the Morgan Stanley Capital International (MSCI) Europe, Australia and Far East (EAFE) Index. The systematic return for each 401(k) investment option is simply its factor exposure times the average factor returns over the period; the participant's factor return is simply the weighted average return of his or her factor exposures over the period. The mean returns of our three factors (CRPS, LBA and EAFE) over the 96-month period are given by:

$\bar{r}_{f}=\left(\bar{r}_{C R S P R F, t}, \bar{r}_{L B A R F, t}, \bar{r}_{M S C I R F, t}\right)$. The systematic return associated with the $k$ th asset is its factor exposure times the average factor returns over the 96 months, namely: $r_{k}^{e}=b_{k}^{\prime} \bar{r}_{f}$. The $i$ th participant's excess return reported in Panel B of Table 3 is $r_{i}^{e}=\sum_{k=1}^{N} \omega_{k, t} r_{k}^{e}$, where $\omega_{i, k, t}$ is the weight of the $k$ th fund in the $i$ th participant's contributions made in month $t$.

${ }^{14}$ Virtually all of the SA funds in our sample included broad exposure to US and international equities, as well as US bonds. Many of the balanced funds did as well, although some were exclusively US-focused.

${ }^{15} N S R / T V_{i, t}=\hat{\Sigma}_{i}^{i d i o} / \hat{\Sigma}_{i}$. We estimate the variance-covariance matrix for all assets $\hat{\Sigma}$, which in turn is used to estimate the total portfolio variance for the $i$ th participant, $\hat{\Sigma}_{i} \cdot \hat{\Sigma}=\hat{\mathrm{B}}^{\prime} \hat{\Sigma}_{f} \hat{\mathrm{B}}+\hat{D}$, where $\hat{D}$ is a diagonal matrix with elements computed as the square of the $\hat{\varepsilon}_{k}$ estimated in equation (2). The asset variance can be decomposed into systematic risk, $\hat{\Sigma}^{s y s}=\hat{\mathrm{B}} \hat{\Sigma}_{f} \hat{\mathrm{B}}$ and idiosyncratic risk $\hat{D}^{\text {idio }}$. Individual portfolio variance can be decomposed into its systematic and idiosyncratic component: $\hat{\Sigma}_{i}=\omega_{i, k, t}^{\prime} \hat{\Sigma} \omega_{i, k, t}=\omega_{i, k, t}^{\prime}\left(\hat{\Sigma}^{s y s}+\hat{D}^{i d i o}\right) \omega_{i, k, t}=\hat{\Sigma}_{i}^{s y s}+\hat{\Sigma}_{i}^{i d i o}$. 
based lifecycle funds. Not surprisingly, given that all of our funds are index-based, this measure of risk is eliminated for pure lifecycle adopters and it falls substantially for mixed adopters.

In a multivariate analysis of portfolio effects, we examine factors associated with the same three portfolio characteristics, namely the individual's allocation to equities, his systematic returns, and his nonsystematic risk. The dependent variables are represented in a vector of portfolio characteristics, PORTFOLIO ${ }_{i, j, t}$, , with the model taking the following form:

$$
\begin{gathered}
\operatorname{PORTFOLIO}_{i, j, t}=\alpha \text { PARTICIPANT }+\beta P L A N+\gamma \text { TREATMENT } \\
+v_{i}+\tau_{t}+\omega_{j}+\varepsilon_{i, j, t}
\end{gathered}
$$

Model A includes just these terms, while Model B adds interaction terms to test whether specific groups display differential treatment patterns when lifecycle funds are introduced. For example, $L C \_$Treat*Young allows us to examine the differential impact of lifecycle treatment on participants under age 35.

Table 6 summarizes estimates for the equity allocation models, differentiating results for pure and mixed adopters. The variable $L C_{-}$Treat in Model A captures the simple change in equity allocation after controlling for differences in participant and plan features, timing and industry fixed effects, and plan-level heteroskedasticity. All else constant, pure adopters devote less to equity (1.8 percentage points) but no change is seen for mixed adopters. Model B adds treatment interactions for participant and plan characteristics, the most important of which is with respect to age. Here it is clear that for pure and mixed adopters, younger workers invest more in equity after lifecycle funds are introduced (LC_Treat $+L C_{-}$Treat*Young), whereas middle-aged and older people reduce their equity share. Figure 1 summarizes the age effects; the old-young difference increases by 8-10 percentage points. It is also worth noting that the 
changes in equity shares by age remains meaningful for mixed adopters, who on average direct one-third of their portfolio contributions to lifecycle funds.

\section{Table 6 and Figure 1 here}

Not only does the overall age variation in equity exposure change when lifecycle funds are introduced, but the distribution also becomes markedly less disperse (see Figure 2). ${ }^{16}$ Whereas many participants had previously held equity holdings at two focal points (0 and 100 percent), and another group held a mid-range of equities (61-65 percent, a typical allocation in many balanced funds), adopters’ portfolios change dramatically after the new funds are offered. For pure adopters (Figure 2A), their revised equity holdings now concentrate around the key target percentages underlying the lifecycle fund offerings. For mixed adopters (Figure 2B), the zero and all-equity allocations are again mostly eliminated, though the changes are smaller. Overall the cross-sectional standard deviation of equity allocations is reduced.

Figure 2 here

Next we consider the impact of lifecycle fund introduction on portfolio efficiency measures. As shown in the first two columns of Table 7, pure adopters can expect higher systematic returns of 19-21 basis points per year when they shift to an all-lifecycle portfolio. The change in the age gradient of equity allocations results in a change in age-related returns: young pure adopters see returns rise by an annualized 13 basis points (.0019-.0006), while older pure adopters can returns fall by 25 basis points $(.0019+.0006)$ per year, partly due to their

\footnotetext{
${ }^{16}$ Corresponding statistics measuring the dispersion of equity allocations are presented in the Appendix, both for plans offering the funds de novo or in substitute for static allocation funds.
} 
having been shifted to more conservative allocations at older ages. ${ }^{17}$ For mixed adopters, depicted in the next two columns of Table 7, changes in returns are not statistically significant.

\section{Table 7 here}

The second half of Table 7 indicates how portfolio nonsystematic risk shares (NSR) change when lifecycle funds are introduced. Not surprisingly, nonsystematic risk virtually disappears for pure adopters who switch their contributions to an all-index life cycle fund. It accounted for 6 percentage points of total variance before lifecycle fund adoption and the marginal effect of shifting to lifecycle funds is a negative 5.1 percentage points. The NSR share falls less for younger participants (-2.9 percentage points) than for older participants (-6.2 percentage points). Changes for mixed adopters are more notable: after moving to lifecycle funds, their NSR risk share declines by over 40 percent (a marginal effect of -8.3 on a mean of 19.9 percentage points). Accordingly, even middle-income mixed adopters who use lifecycle funds for only portion of their portfolios will still experience a meaningful reduction in nonsystematic risk exposure. In effect, we have another measure of the spillover effect: a reduction in idiosyncratic risk intended for the pure adopter spills over into a broader population of investors.

These results highlight the power of framing effects on the structure of portfolio decisions. For pure investors electing lifecycle funds on a voluntary basis, adopting the lifecycle offerings boosts equity exposure with age, eliminates extreme asset allocations, enhances portfolio efficiency, and reduces nonsystematic risk exposure. Our results also identify

\footnotetext{
${ }^{17}$ Pure lifecycle investors generally liquidate cash investments and shift their fixed income to bonds. Cash investments have zero excess returns by definition, while over our study period, bonds earned excess returns of 23 basis points per month. Our younger pure adopters moved from a cash exposure of $3 \%$ to $0 \%$ when moving to lifecycle funds, while older participants moved from $9 \%$ to $0 \%$. For mixed adopters, younger participants reduced equity holdings slightly, from $8 \%$ to $6 \%$, while older participants moved from $11 \%$ to $9 \%$.
} 
meaningful and interesting spillover effects for mixed adopters, where introducing life cycle funds compresses the variability in equity holdings, reduces extreme allocations, and curtails nonsystematic risk - even when they do not move entirely into the lifecycle options. Spillover effects, in other words, extend beyond adoption outcomes to reshape portfolio risk and return characteristics.

\section{Discussion}

Default, framing, and other behaviorally-based strategies have been proposed in several domains as a possible alternative to the need for enhanced consumer protection. In the pension environment, this approach has prompted policy reforms including automatic enrollment and the creation of a new class of designated default investments for 401(k) plans. Our paper considers whether default and framing effects are a sufficient explanation for the behavioral outcomes that arise from a change in the choice architecture. We use the introduction of lifecycle funds into 401(k) plans as a consequential decision-making environment for assessing this question.

Our findings demonstrate that changes in a given choice architecture, while having expected default and framing effects, can also have important unanticipated or spillover effects. Specifically, we find, as anticipated, strong evidence of default and framing effects: adoption rates among pure investors, investing as intended in a single lifecycle fund, are nearly $60 \%$ higher when the funds are designated as a default investment option. Also, in voluntary (nondefault) settings, the funds are chosen by individuals with characteristics often associated with low levels of financial experience, namely young, low-income, and low-wealth investors. Because the lifecycle funds add no new asset classes to the retirement plans we examined, this 
effect measures the appeal of the unique decision framing offered by a lifecycle fund-replacing the portfolio construction process with the choice of an expected retirement date.

But the introduction of lifecycle funds also produces a large spillover effect, namely, the creation of a large group of mixed investors who utilize lifecycle funds in a more complex approach to retirement saving. While this was an unexpected result from lifecycle fund introduction, the effect is sizeable: the group of mixed investors is only slightly smaller than the pure investors. Moreover, "mixed" adopters are typically middle-income and middle-wealth investors, not characteristics typically associated with low levels of sophistication or naive diversification. The spillover effect does result in meaningful changes to these mixed adopter portfolios. These include less extreme portfolio allocations, more age-based variation in equity exposure, and less idiosyncratic risk.

These results are directly relevant for retirement policymakers and plan sponsors seeking to influence investment patterns in 401(k) plans. To the extent that the simplified framing of lifecycle funds appeals to participants with characteristics indicative of low financial sophistication, the designation of such funds as a default can markedly enhance portfolio allocations for the least-informed group. Also lifecycle funds have been proposed for the federal government employee Thrift Savings Plan, some state defined contribution schemes, and a defined contribution plan suggested for the US Social Security system. Other countries such as Chile currently use lifecycle-type funds as the default in their national defined contribution systems.

Our analysis also holds implication for "choice architects" in other domains seeking to remedy perceived deficiencies in individual decision-making with a range of behaviorallyinformed strategies. While default and framing do have a powerful role in altering individual 
behavior, these are an incomplete explanation of the impact of changing the decision environment. Thus, when altering choice architectures, it is critical to understand the potential spillover effects that might occur, the magnitude of such effects, and whether their impact might be judged to be detrimental or benign. 


\section{References}

Agnew, Julie, Pierluigi Balduzzi, and Annika Sunden. 2003. "Portfolio Choice and Trading in a Large 401(k) Plan,” American Economic Review, 93(1): 193-215.

Ameriks, John and Stephen Zeldes. 2001. “How Do Household Portfolio Shares Vary with Age?” TIAA-CREF Institute Working Paper 6-120101.Working Paper.

Benartzi, Shlomo. 2001. "Excessive Extrapolation and the Allocation of 401(k) Accounts to Company Stock.” Journal of Finance. October. 56(5). 1747-1764.

Benartzi, Shlomo and Richard H. Thaler. 2001. "Naïve Diversification Strategies in Defined Contribution Savings Plans.” American Economic Review. March. 91(1): 79-98.

Benartzi, Shlomo and Richard H. Thaler. 2002. "How Much Is Investor Autonomy Worth?" Journal of Finance. August. 57(4): 1593-1616.

Benartzi, Shlomo, Ehud Peleg, and Richard H. Thaler. 2007. "Choice Architecture and Retirement Savings Plans.” Working paper. http://ssrn.com/abstract=999420.

Brown, Jeffrey R., Nellie Lang and Scott Weisbenner. 2007. “Individual Account Investment Options and Portfolio Choice: Behavioral Lessons from 401(k) Plans.” NBER Working Paper 13169 June.

Calvet, Laurent E., John Y. Campbell, and Paolo Sodini. 2009. "Fight or Flight? Portfolio Rebalancing by Individual Investors.” Quarterly Journal of Economics. 124: 301-348.

Choi, James J., David Laibson, Brigitte C. Madrian, and Andrew Metrick. 2003. "Optimal Defaults." American Economic Review. 93:180-185.

Choi, James J., David Laibson, and Brigitte C. Madrian. 2004. "Plan Design and 401(k) Savings Outcomes." National Tax Journal. 57:275-298.

Choi, James J., David Laibson, Brigitte C. Madrian, and Andrew Metrick. 2006. “Saving for Retirement on the Path of Least Resistance.” Ed McCaffrey and Joel Slemrods, eds., Behavioral Public Finance: Toward a New Agenda. 304-351.

Huberman, Gur and Wei Jiang. 2006. “Offering vs. Choices in 401(k) Plans: Equity Exposure and Number of Funds.” Journal of Finance. XLI(2): 763-801.

Iyengar, Sheena, Gur Huberman and Wei Jiang. 2004. "How Much Choice is Too Much? Contributions to 401(k) Retirement Plans.” In Pension Design and Structure: New Lessons from Behavioral Finance, Olivia S. Mitchell and Stephen P. Utkus, eds. Oxford: Oxford University Press: 83-96. 
Iyengar, Sheena, and Wei Jiang. 2006. "The Psychological Costs of Ever Increasing Choice: A Fallback to the Sure Bet.” Working paper.

Lusardi, Annamaria and Olivia S. Mitchell. 2007. "Baby Boomer Retirement Security: The Role of Planning, Financial Literacy and Housing Health. Journal of Monetary Economics. 54(1) January: 205-224.

Madrian, Brigitte, and D.F. Shea. 2001. “The Power of Suggestion: Inertia in 401(k) Participation and Savings Behavior.” Quarterly Journal of Economics 116: 1149-1525.

Mitchell, Olivia S., Gary R. Mottola, Stephen P. Utkus, and Takeshi Yamaguchi. 2006a. "The Inattentive Participant: Portfolio Trading Behavior in 401(k) Plans.” Pension Research Council Working Paper 2006-05. Philadelphia, PA.: Wharton School.

Mitchell, Olivia S., Gary R. Mottola, Stephen P. Utkus and Takeshi Yamaguchi. 2006b. "Winners and Losers: 401(k) Trading and Portfolio Performance.” Pension Research Council Working Paper 2006-26. Philadelphia, PA.: Wharton School.

Nessmith, William E., Stephen P. Utkus, and Jean A. Young. 2007. "Measuring the Effectiveness of Automatic Enrollment." Vanguard Center for Retirement Research, Malvern, PA. www.vanguard.com/retirementresearch.

O’Donoghue, Ted, and Matthew Rabin. 1999. “Procrastination in Preparing for Retirement.” In Henry Aaron, ed., Behavioral Dimensions of Retirement Economics. Brookings Institution Press and Russell Sage Foundation.

O’Donoghue, Ted, and Matthew Rabin. 2001. “Choice and Procrastination,” Quarterly Journal of Economics. Feb 2001. 121-160.

Thaler, Richard and Cass Sunstein. 2008. Nudge: Improving Decisions About Health, Wealth, and Happiness. New Haven: Yale University Press. 


\section{Table 1. Characteristics of Lifecycle Funds Introduced}

A. Portfolio Mix of Lifecycle Funds by Target Date

\begin{tabular}{lcccc} 
& US Equities & Int'I Equities & US Bonds & $\begin{array}{c}\text { Equity } \\
\text { Share } \\
\%\end{array}$ \\
\hline 2045 Fund & 71 & $\%$ & $\%$ & $\%$ \\
2035 Fund & 71 & 18 & 11 & 89 \\
2025 Fund & 63 & 18 & 11 & 89 \\
2015 Fund & 50 & 13 & 31 & 79 \\
2005 Fund & 35 & 9 & 56 & 63 \\
Income Fund & 24 & 5 & 71 & 29 \\
\hline
\end{tabular}

B. Introduction Patterns of Lifecycle (LC) Funds

\begin{tabular}{l|rc|rc|rc|} 
& \multicolumn{2}{|c|}{ Plans } & \multicolumn{2}{|c|}{ Participants } & \multicolumn{2}{|c|}{ LC adopters } \\
& \multicolumn{1}{|c|}{$\mathrm{N}$} & $\%$ & \multicolumn{1}{|c}{$\mathrm{N}$} & $\%$ & $\mathrm{~N}$ & $\%$ \\
\hline 1. De Novo Life Cycle (LC) & 117 & 0.45 & 113,560 & 0.45 & 3,541 & 0.14 \\
2. Added LC to SA & 83 & 0.32 & 99,201 & 0.39 & 12,509 & 0.51 \\
3. Switch from SA to LC & 58 & 0.22 & 40,219 & 0.16 & 8,562 & 0.35 \\
\hline Total & 258 & & 252,980 & & 24,612
\end{tabular}

Note: Panel A tabulates asset mix as of 9/07. Static allocation (SA) refer to prior risk-based funds; see text. Source: Authors' tabulations. 
Table 2. Participant and Plan Characteristics

\begin{tabular}{|c|c|c|c|c|}
\hline \multirow[b]{2}{*}{ Variable } & \multirow[b]{2}{*}{$\begin{array}{c}\text { Full Sample } \\
1\end{array}$} & \multicolumn{3}{|c|}{ Difference-in-Difference Sample } \\
\hline & & $\begin{array}{c}\text { All } \\
\text { Adopters } \\
2\end{array}$ & $\begin{array}{c}\text { Pure } \\
\text { Adopters } \\
3\end{array}$ & $\begin{array}{c}\text { Mixed } \\
\text { Adopters } \\
4\end{array}$ \\
\hline \multicolumn{5}{|l|}{ Age (\%) } \\
\hline $\overrightarrow{\text { Young }(<35)}$ & 25 & 28 & 33 & 24 \\
\hline Middle (35-55) & 59 & 59 & 55 & 62 \\
\hline Old $(>55)$ & 16 & 13 & 12 & 13 \\
\hline \multicolumn{5}{|l|}{$\operatorname{Sex}(\%)$} \\
\hline$\overline{\text { Male }}$ & 45 & 41 & 31 & 49 \\
\hline Female & 26 & 30 & 33 & 28 \\
\hline Missing & 29 & 28 & 36 & 22 \\
\hline \multicolumn{5}{|l|}{ Income (\%) } \\
\hline Low $(<\$ 62.5 \mathrm{~K})$ & 19 & 23 & 25 & 21 \\
\hline Medium $(\$ 62.5-\$ 87.5 \mathrm{~K})$ & 39 & 39 & 44 & 36 \\
\hline High (> \$87.5K) & 41 & 38 & 30 & 43 \\
\hline \multicolumn{5}{|l|}{ Tenure (\%) } \\
\hline New Hire & 18 & na & na & na \\
\hline 401(k) Balance (\$ av.) & 64,065 & 50,032 & 34,289 & 62,240 \\
\hline \multicolumn{5}{|c|}{ Non-ret. Financial Wealth (\%) } \\
\hline Poor $(<\$ 7.3 \mathrm{~K})$ & 42 & 41 & 44 & 39 \\
\hline Average $(\$ 7.3-\$ 61 \mathrm{~K})$ & 35 & 37 & 36 & 38 \\
\hline Rich $(>\$ 61 \mathrm{~K})$ & 23 & 22 & 20 & 23 \\
\hline \multicolumn{5}{|c|}{ Plan Feature ( $\%$ of participants) } \\
\hline Employer Stock Offered & 31 & 26 & na & na \\
\hline Loan Offered & 67 & 62 & na & na \\
\hline N Funds Offered (mean) & 34.2 & 33.0 & na & na \\
\hline \multicolumn{5}{|l|}{ Observations } \\
\hline N Plans & 258 & 251 & 228 & 234 \\
\hline N Participant Accounts & 252,980 & 24,612 & 10,750 & 13,862 \\
\hline
\end{tabular}

Notes:

1. Characteristics are as of 12/5 for the full sample and six months after lifecycle introduction for the difference-indifference sample.

2. The difference-in-difference sample includes participants choosing lifecycle funds who were continuously employed during the sample period (i.e., new entrants are excluded).

Source: Authors' tabulations. 
Table 3. Multivariate Probit Analysis of the Probability of Being a Lifecycle (LC) Adopter (Dependent variable $=1$ if Lifecycle Adopter, 0 else; mean $=15.1 \%$ )

\begin{tabular}{|c|c|c|c|}
\hline & Mean & Coefficient & $\begin{array}{c}\text { Marginal } \\
\text { Effects (\%) }\end{array}$ \\
\hline \multicolumn{4}{|l|}{ Lifecycle Treatment } \\
\hline Default (\%) & 11 & $0.565 * \star \star$ & 10.9 \\
\hline New Entrant*Default & & $0.189 * * *$ & 3.6 \\
\hline Mos Since LC & 9.3 & $0.011 * \star \star$ & 0.2 \\
\hline Mos**2 Since LC & 120.7 & $0.000 * * *$ & 0.0 \\
\hline \multicolumn{4}{|c|}{ Socioeconomic Factors (\%) } \\
\hline Young & 23 & $0.121 * \star \star$ & 2.3 \\
\hline Old & 16 & $-0.103 * * *$ & -2.0 \\
\hline Male & 45 & $-0.067 * * \star$ & -1.3 \\
\hline Low_Income & 20 & $-0.029 * * *$ & -0.5 \\
\hline High_Income & 40 & -0.003 & -0.1 \\
\hline Poor_Wealth & 38 & $0.035 * \star \star$ & 0.7 \\
\hline Rich_Wealth & 26 & $-0.092 * * *$ & -1.8 \\
\hline Log Balance & $\$ 9.77$ & $-0.063 * \star \star$ & -1.2 \\
\hline New Entrant & 11 & $0.342 * \star \star$ & 6.6 \\
\hline \multicolumn{4}{|l|}{ Plan Design (\%) } \\
\hline SA_Before & 61 & $0.880 * * *$ & 16.9 \\
\hline Co. Stock Offered & 26 & $0.1011^{* * *}$ & 1.9 \\
\hline Loan Offered & 59 & -0.0304 & -0.6 \\
\hline N Funds & 38.9 & $-0.0112 * \star *$ & -0.2 \\
\hline \multicolumn{4}{|l|}{ Controls } \\
\hline Participant Clustering & & Yes & \\
\hline Time Fixed Effect & & Yes & \\
\hline Industry Fixed Effect & & Yes & \\
\hline Observations & & $3,178,373$ & \\
\hline Number of Clusters & & 252,980 & \\
\hline$-2 \log L$ & & $2,692,640$ & \\
\hline Pseudo-R Squared & & $11.62 \%$ & \\
\hline
\end{tabular}

Notes: The model is a Probit regression of lifecycle adoption using the full sample of over 250,000 participants. It controls for how lifecycle funds were introduced ("lifecycle treatment”), demographic control variables for participants ("socioeconomic factors"), and elements of plan design that vary at the firm level ("plan design). Reference categories include middle income; middle wealth; female (missing variables are dummied). Models include participant clustering within plans, and time and industry fixed effects. ** Significant at the .05 level; *** Significant at the .01 level.

Source: Authors' tabulations. 
Table 4. Marginal Effects from Multinomial Logit Model of the Probability of Being a Pure or Mixed Lifecycle (LC) Adopter

(Reference Group: Non adopter; Pure adopters = 8.6\%, Mixed adopters 7.7\%)

\begin{tabular}{|c|c|c|c|}
\hline & Mean & $\begin{array}{c}\text { Pure Adopter } \\
\text { Marginal Effect (\%) }\end{array}$ & $\begin{array}{c}\text { Mixed Adopter } \\
\text { Marginal Effect (\%) }\end{array}$ \\
\hline \multicolumn{4}{|l|}{ Lifecycle Treatment } \\
\hline Default (\%) & 10 & $5.0 * \star *$ & $1.6 * \star \star$ \\
\hline Default*New Entrant & & $1.6 * \star \star$ & $-1.0 * \star \star$ \\
\hline Time Count & 8.6 & $0.4 * \star *$ & $-0.1 * \star \star$ \\
\hline Time Count Squared & 120.7 & $0.0 * * *$ & $0.0 * * *$ \\
\hline \multicolumn{4}{|c|}{ Socioeconomic Characteristics (\%) } \\
\hline Young & 24 & $0.9 * \star \star$ & $0.5 * \star \star$ \\
\hline Old & 16 & $-0.5 * * *$ & $-0.7 * \star \star$ \\
\hline Male & 43 & $-0.9 * * *$ & $-0.2 * \star *$ \\
\hline Low_Income & 20 & 0.2 ** & $-0.3 * * \star$ \\
\hline High_Income & 39 & -0.2 & 0.0 \\
\hline Poor_Wealth & 38 & $0.5 * * *$ & 0.0 \\
\hline Rich_Wealth & 25 & $-0.8 * * *$ & $-0.4 * \star *$ \\
\hline Log Balance & $\$ 9.80$ & $-0.7 * * *$ & $0.0 * \star$ \\
\hline New Entrant & 11 & $2.1 * \star \star$ & $1.5 * * \star$ \\
\hline \multicolumn{4}{|l|}{ Plan Design (\%) } \\
\hline SA_Before & 57 & $3.8 * \star \star$ & $5.0 * \star \star$ \\
\hline Co. Stock Offered & 31 & $-1.6 * \star *$ & $1.2 * \star *$ \\
\hline Loan Offered & 61 & $-1.2 * \star \star$ & $0.4 * \star \star$ \\
\hline $\mathrm{N}$ funds & 37.6 & $-0.1 * \star \star$ & $0.0 * \star \star$ \\
\hline \multicolumn{4}{|l|}{ Controls } \\
\hline Participant Clustering & & Yes & Yes \\
\hline Time Fixed Effect & & Yes & Yes \\
\hline Industry Fixed Effext & & Yes & Yes \\
\hline Observations & & $3,178,373$ & $3,178,373$ \\
\hline Number of Clusters & & 252,980 & 252,980 \\
\hline$-2 \log L$ & & $3,354,106$ & $3,354,106$ \\
\hline Pseudo-R Squared & & $15.34 \%$ & $15.34 \%$ \\
\hline
\end{tabular}

Notes: The model is a multinomial Logit regression of lifecycle adoption using the full sample of over 250,000 participants. It compares mixed adopters (those holding lifecycle funds with other funds) and pure adopters (those holding only one lifecycle fund) versus all other participants who do not adopt lifecycle funds (the reference group for the dependent variable). See Table 3 for additional information on the independent variables. ${ }^{* *}$ Significant at the .05 level; *** Significant at the .01 level.

Source: Authors' tabulations. 
Table 5. Contribution Allocations and Portfolio Risk/Return Characteristics Pre/Post Introduction of Lifecycle Funds (Difference-in-Difference Sample)

A. Contribution Allocations (\%)

\begin{tabular}{|c|c|c|c|c|c|c|c|}
\hline & & $\begin{array}{l}\text { Cash } \\
\text { (MMkt, } \\
\text { GIC) }\end{array}$ & Bonds & $\begin{array}{l}\text { Balanced, } \\
\text { Lifecycle }\end{array}$ & $\begin{array}{l}\text { U.S. } \\
\text { Equities }\end{array}$ & $\begin{array}{l}\text { Int'l } \\
\text { Equities }\end{array}$ & $\begin{array}{l}\text { Company } \\
\text { Stock }\end{array}$ \\
\hline \multirow[t]{3}{*}{ All Adopters } & Pre & 7.1 & 5.2 & 54.2 & 27.9 & 2.9 & 2.7 \\
\hline & Post & 3.7 & $\underline{3.6}$ & $\underline{66.1}$ & 21.7 & 2.7 & $\underline{2.3}$ \\
\hline & Change & -3.4 & -1.7 & 11.9 & -6.2 & -0.3 & -0.4 \\
\hline \multirow[t]{3}{*}{ Pure Adopters } & Pre & 4.9 & 2.9 & 79.4 & 11.3 & 0.9 & 0.5 \\
\hline & Post & $\underline{0.0}$ & $\underline{0.0}$ & $\underline{100.0}$ & $\underline{0.0}$ & $\underline{0.0}$ & $\underline{0.0}$ \\
\hline & Change & -4.9 & -2.9 & 20.6 & -11.3 & -0.9 & -0.5 \\
\hline \multirow[t]{3}{*}{ Mixed Adopters } & Pre & 8.7 & 7.0 & 34.7 & 40.8 & 4.5 & 4.3 \\
\hline & Post & $\underline{6.5}$ & $\underline{6.3}$ & $\underline{39.8}$ & $\underline{38.6}$ & $\underline{4.8}$ & $\underline{4.0}$ \\
\hline & Change & -2.2 & -0.7 & 5.1 & -2.2 & 0.2 & -0.3 \\
\hline
\end{tabular}

B. Portfolio Risk/Return Characteristics (\%)

\begin{tabular}{|c|c|c|c|c|}
\hline & & $\begin{array}{r}\text { Equity } \\
\text { Alloca- } \\
\text { tions }\end{array}$ & $\begin{array}{r}\text { Syste- } \\
\text { matic } \\
\text { Returns }\end{array}$ & NSR/TV* \\
\hline \multirow[t]{3}{*}{ All Adopters } & Pre & 66.6 & 6.46 & 13.8 \\
\hline & Post & $\underline{68.1}$ & $\underline{6.70}$ & $\underline{10.0}$ \\
\hline & Change & $\overline{1.4}$ & $\overline{0.24}$ & -3.8 \\
\hline \multirow[t]{3}{*}{ Pure Adopters } & Pre & 61.4 & 6.38 & 6.0 \\
\hline & Post & $\underline{62.4}$ & $\underline{6.63}$ & $\underline{0.9}$ \\
\hline & Change & 1.0 & $\overline{0.25}$ & $-\overline{5.0}$ \\
\hline \multirow[t]{3}{*}{ Mixed Adopters } & Pre & 70.7 & 6.52 & 19.9 \\
\hline & Post & $\underline{72.5}$ & $\underline{6.76}$ & $\underline{17.1}$ \\
\hline & Change & 1.8 & $\overline{0.24}$ & -2.8 \\
\hline
\end{tabular}

Notes: * Nonsystematic risk as a percent of total variance (see text). Equity allocations are the percentage of contributions invested in U.S. or international equities (including equity funds and the equity portfolio of balance, lifecycle and other hybrid funds). Systematic returns refer to excess factor returns relative to the risk-free rate (see text). Non-systematic risk is the idiosyncratic or non-market risk borne by investors (the portion due to deviating from a market index portfolio).

Source: Authors' tabulations. 
Table 6. Marginal Effects from Multivariate Model of Portfolio Equity Allocations (\%; Difference-in-Difference Sample)

\begin{tabular}{|c|c|c|c|c|}
\hline & \multicolumn{2}{|c|}{ Pure Adopters } & \multicolumn{2}{|c|}{ Mixed Adopters } \\
\hline & Model A & Model B & Model A & Model B \\
\hline \multicolumn{5}{|l|}{ Treatment } \\
\hline LC_treat & $-0.018 * * *$ & $-0.032 * \star \star$ & -0.006 & $-0.013 * *$ \\
\hline LC_treat*Young & & $0.064 * \star \star$ & & $0.043 * * *$ \\
\hline LC_treat*Old & & $-0.040 * \star \star$ & & $-0.035 * * \star$ \\
\hline LC_treat*Low_Income & & 0.000 & & 0.004 \\
\hline LC_treat*High_Income & & -0.004 & & 0.000 \\
\hline LC_treat*Male & & $-0.016 * \star \star$ & & -0.008 *** \\
\hline LC_treat*Poor_Wealth & & $0.019 * \star \star$ & & 0.007 \\
\hline LC_treat*Rich_Wealth & & -0.008 & & 0.008 \\
\hline \multicolumn{5}{|l|}{ Socioeconomic Factors } \\
\hline Young & $0.006 * * *$ & $0.022 * \star \star$ & $0.052 * \star \star$ & $0.031 * * *$ \\
\hline Old & $-0.105 * \star \star$ & $-0.085 * \star \star$ & $-0.078 * * *$ & $-0.060 * * *$ \\
\hline Male & $0.010 * \star$ & $0.019 * \star \star$ & $0.019 * \star \star$ & $0.023 * \star *$ \\
\hline Low_Income & 0.004 & 0.004 & $-0.015 * * *$ & $-0.017 * * *$ \\
\hline High_Income & 0.001 & 0.004 & 0.006 & 0.007 \\
\hline Poor_Wealth & 0.007 & -0.005 & $-0.012 * * *$ & $-0.016 * * *$ \\
\hline Rich_Wealth & $0.010 * *$ & $0.013 * \star$ & 0.005 & 0.001 \\
\hline Log Balance & $0.006 * \star *$ & $0.005 * \star \star$ & $0.016^{* \star *}$ & $0.016 * * *$ \\
\hline \multicolumn{5}{|l|}{ Plan Design } \\
\hline SA_Before & $-0.061 * * *$ & $-0.062 * \star \star$ & 0.005 & 0.004 \\
\hline Co.Stock Offered & -0.006 & -0.004 & $0.022 * * *$ & $0.022 * * *$ \\
\hline Loan Offered & $0.074 * * *$ & $0.074 * * *$ & 0.011 & 0.011 \\
\hline N Funds & $0.005 * \star *$ & $0.005 * \star *$ & 0.000 & 0.000 \\
\hline \multicolumn{5}{|l|}{ Controls } \\
\hline Participant-level clustering & Yes & Yes & Yes & Yes \\
\hline Time Fixed Effects & Yes & Yes & Yes & Yes \\
\hline Industry Fixed Effects & Yes & Yes & Yes & Yes \\
\hline Observations & 21,500 & 21,500 & 27,724 & 27,724 \\
\hline \# of Participants & 10,750 & 10,750 & 13,862 & 13,862 \\
\hline R Squared & 0.19 & 0.20 & 0.06 & 0.06 \\
\hline \multicolumn{5}{|l|}{ Dependent Means (\%) } \\
\hline Pre-treat & 61.4 & & 70.7 & \\
\hline Post-treat & 62.4 & & 72.5 & \\
\hline Unadjusted difference & 1.0 & & 1.8 & \\
\hline
\end{tabular}

Note: The model is an OLS regression based on the difference-in-difference sample of lifecycle investors. The model regresses portfolio equity allocations on a variety of treatment, socioeconomic and plan-level characteristics. Clustering and fixed effects are as described in Table 3.

Source: Authors' tabulations. 
Table 7. Marginal Effects of Multivariate Model of Lifecycle Treatment on Portfolio Characteristics (\%; Difference-in-Difference Sample)

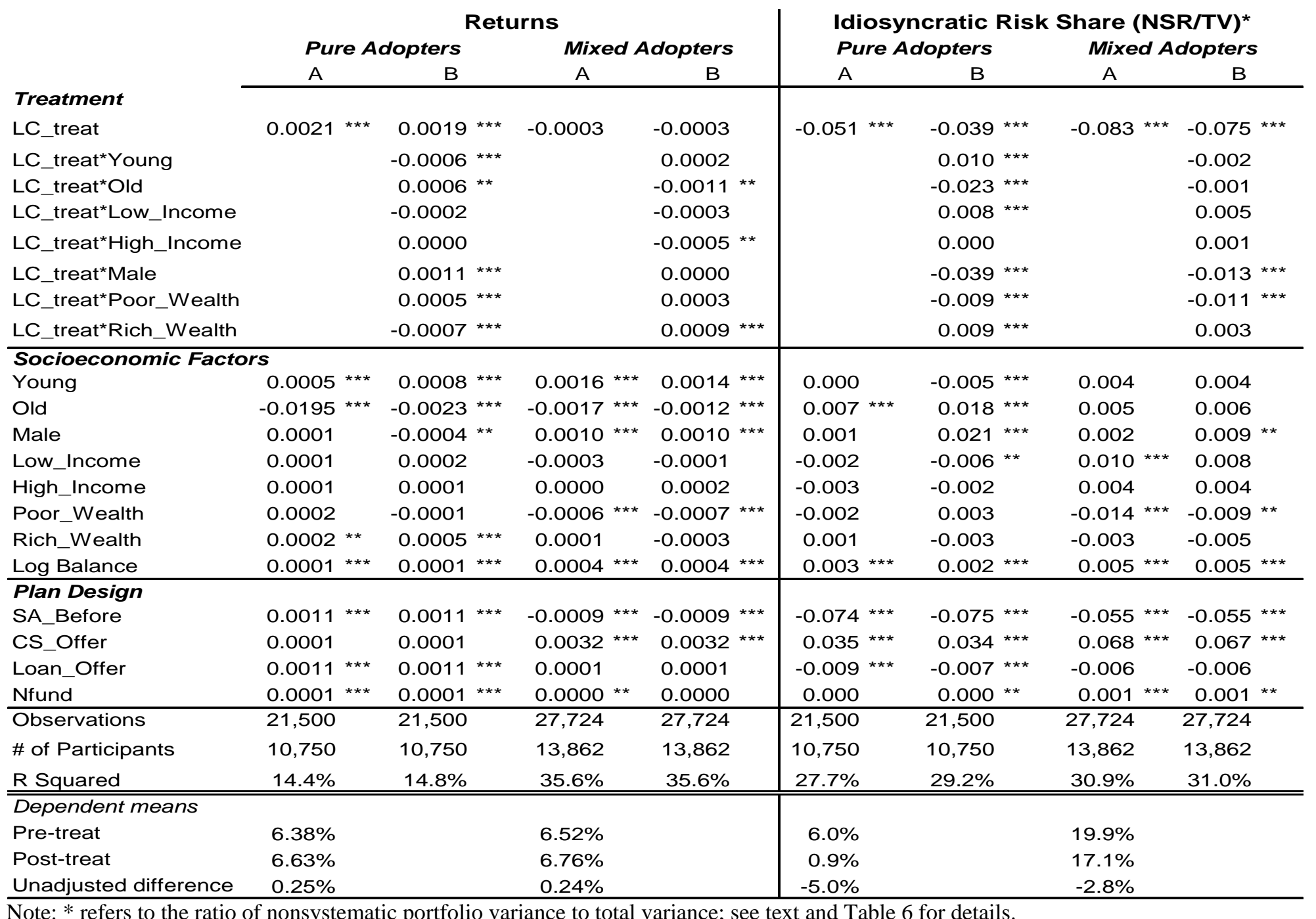

Note: * refers to the ratio of nonsystematic portfolio variance to total variance; see text and Table 6 for details. 
Figure 1. Change in Equity Proportion After Lifecycle Fund Introduction: Patterns by Age for Pure and Mixed Adopters (Difference-in-Difference Sample)

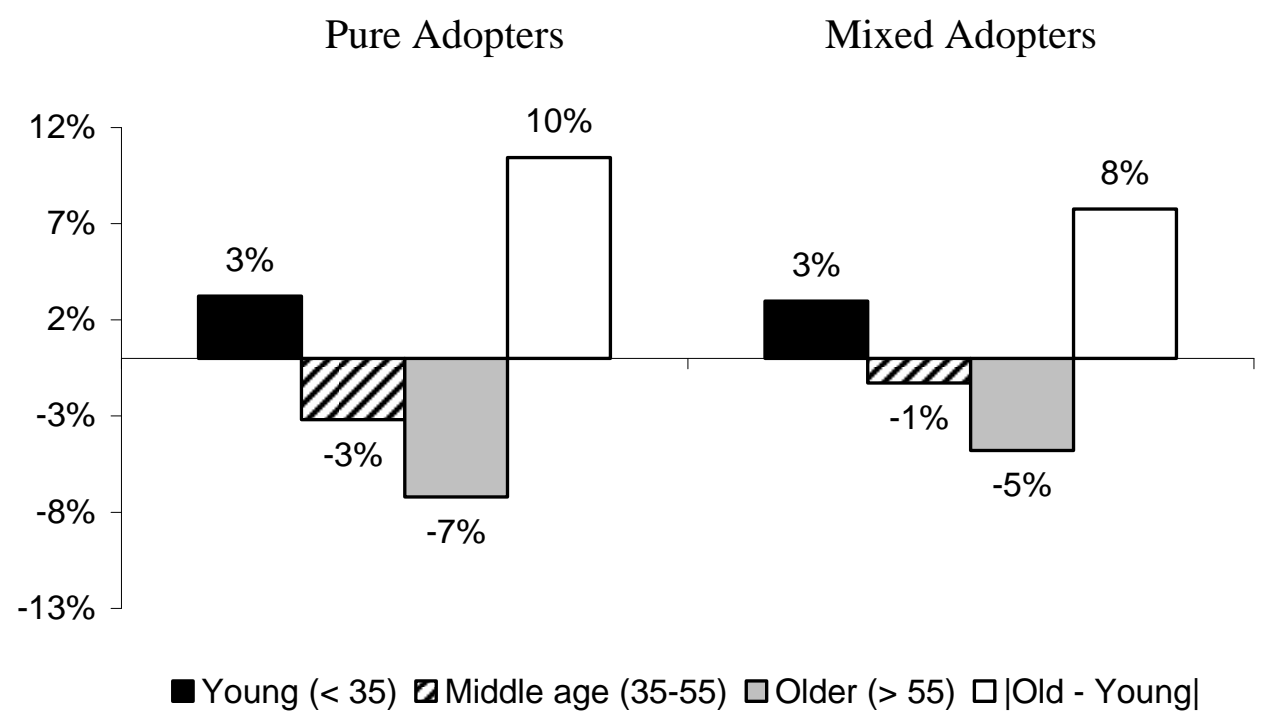

Source: Authors’ tabulations. 
Figure 2. Equity Allocations of Lifecycle Adopters: Before and After Adoption Difference-in-Difference Sample

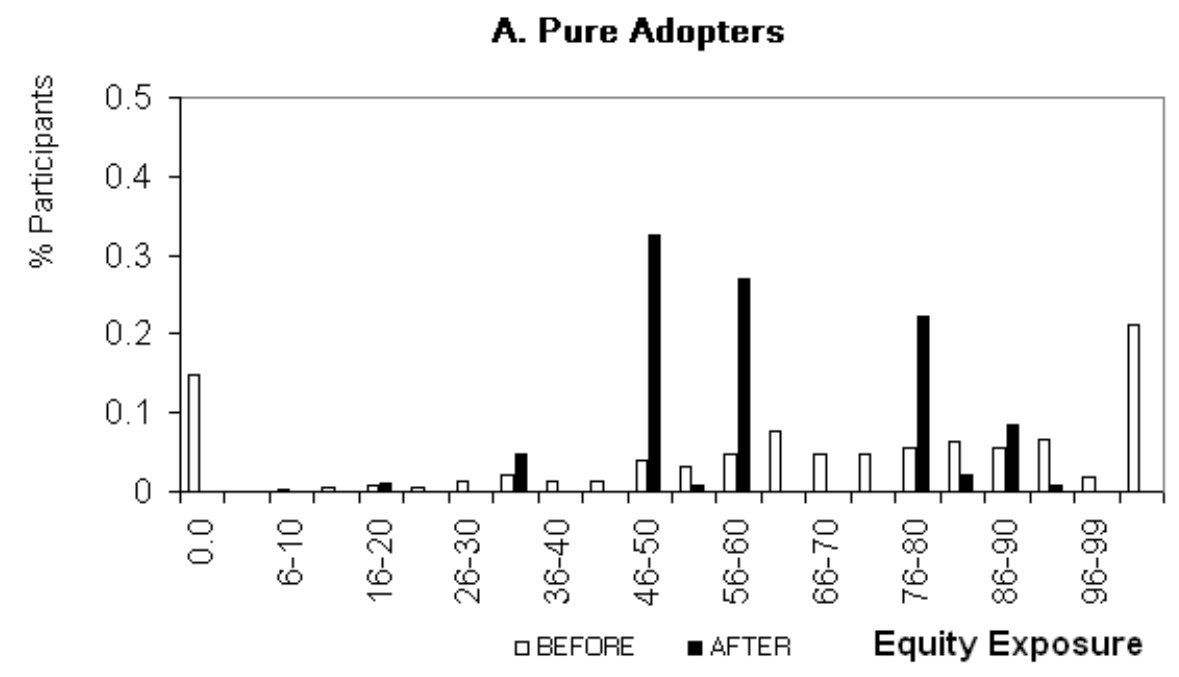

B. Mixed Adopters

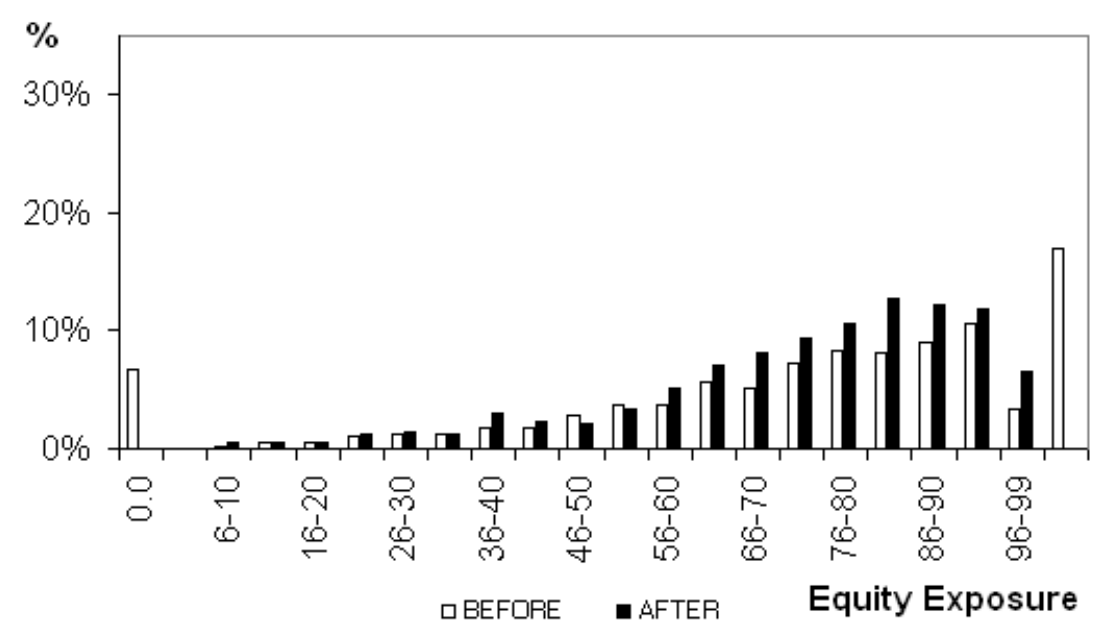

Note: No SA (static allocation funds) were offered prior to LC introduction.

Source: Authors' tabulations. 
Appendix. Cross-sectional Variation in Equity Exposure

(\%; Difference-in-Difference Sample)

\begin{tabular}{lcccccc} 
& \multicolumn{2}{c}{ Pure adopters } & \multicolumn{2}{c}{ Mixed adopters } & \multicolumn{2}{c}{ All adopters } \\
& Mean & St. Dev. & Mean & St. Dev. & Mean & St. Dev. \\
\cline { 2 - 7 } No SA before & & & & & & \\
$\quad$ Before & 64.2 & 0.34 & 71.8 & 0.28 & 68.0 & 0.31 \\
$\quad$ After & 62.8 & 0.16 & 72.6 & 0.19 & 67.7 & 0.18 \\
\% Change & -2 & -53 & 1 & -32 & -1 & -42 \\
SA before & & & & & & \\
$\quad$ Before & 60.9 & 0.22 & 70.6 & 0.23 & 66.4 & 0.23 \\
After & 62.4 & 0.19 & 72.5 & 0.21 & 68.2 & 0.21 \\
\% Change & 2 & -14 & 3 & -9 & 3 & -9 \\
All adopters & & & & & & \\
Before & 61.4 & 0.24 & 70.7 & 0.24 & 66.6 & 0.24 \\
After & 62.4 & 0.18 & 72.5 & 0.20 & 68.1 & 0.20 \\
\% Change & 2 & -25 & 3 & -17 & 2 & -17 \\
\hline
\end{tabular}

Source: Authors’ tabulations. 